\title{
\begin{tabular}{l|l} 
Mibraries & DSpace@MIT
\end{tabular}
}

MIT Open Access Articles

\section{Biochemical and Spectroscopic Observation of Mn(II) Sequestration from Bacterial Mn(II) Transport Machinery by Calprotectin}

The MIT Faculty has made this article openly available. Please share how this access benefits you. Your story matters.

Citation: Hadley, Rose C. et al. "Biochemical and Spectroscopic Observation of Mn(II) Sequestration from Bacterial Mn(II) Transport Machinery by Calprotectin." Journal of the American Chemical Society 140 (2018): 110-113 (c) 2018 The Author(s)

As Published: https://dx.doi.org/10.1021/JACS.7B11207

Publisher: American Chemical Society (ACS)

Persistent URL: https://hdl.handle.net/1721.1/125599

Version: Author's final manuscript: final author's manuscript post peer review, without publisher's formatting or copy editing

Terms of Use: Article is made available in accordance with the publisher's policy and may be subject to US copyright law. Please refer to the publisher's site for terms of use. 
Published in final edited form as:

J Am Chem Soc. 2018 January 10; 140(1): 110-113. doi:10.1021/jacs.7b11207.

\title{
Biochemical and Spectroscopic Observation of Mn(II) Transfer Between Bacterial Mn(II) Transport Machinery and Calprotectin
}

\author{
Rose C. Hadley ${ }^{1}$, Derek M. Gagnon ${ }^{2}$, Megan Brunjes Brophy ${ }^{1}$, Yu Gu${ }^{1}$, Toshiki G. \\ Nakashige $^{1}$, R. David Britt ${ }^{2}$, and Elizabeth M. Nolan ${ }^{1,{ }^{*}}$ \\ ${ }^{1}$ Department of Chemistry, Massachusetts Institute of Technology, Cambridge, MA 02139, United \\ States \\ 2Department of Chemistry, University of California Davis, Davis, CA 95616, United States
}

\begin{abstract}
Human calprotectin (CP, S100A8/S100A9 oligomer) is a metal-sequestering host-defense protein that prevents bacterial acquisition of $\mathrm{Mn}$ (II). In this work, we investigate $\mathrm{Mn}$ (II) competition between CP and two solute-binding proteins that Staphylococcus aureus and Streptococcus pneumoniae, Gram-positive bacterial pathogens of significant clinical concern, use to obtain $\mathrm{Mn}$ (II) when infecting a host. Biochemical and electron paramagnetic resonance (EPR) spectroscopic analyses demonstrate that $\mathrm{CP}$ outcompetes staphylococcal MntC and streptococcal PsaA for $\mathrm{Mn}$ (II). This behavior requires the presence of excess $\mathrm{Ca}$ (II) ions, which enhance the $\mathrm{Mn}$ (II) affinity of CP. This report presents new spectroscopic evaluation of two Mn(II) proteins important for bacterial pathogenesis, direct observation of $\mathrm{Mn}$ (II) transfer from the bacterial $\mathrm{Mn}(\mathrm{II})$ acquisition proteins to $\mathrm{CP}$, and molecular-level insight into the extracellular battle for metal nutrients that occurs during infection.
\end{abstract}

\section{TOC graphic}

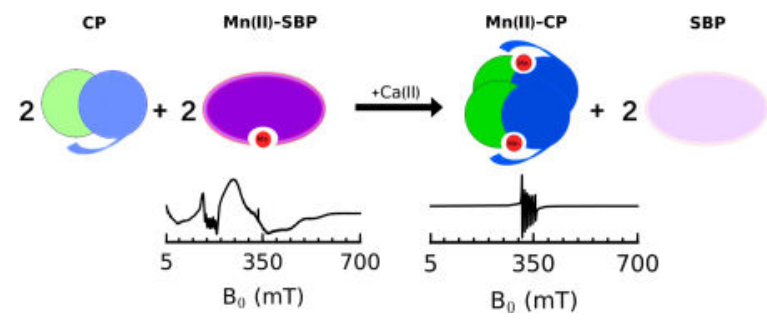

Transition metal ions are essential nutrients for all organisms. In the context of the host/ pathogen interaction, microbes must acquire nutrient metals from the host environment. In response to invading pathogens, the mammalian innate immune system launches a metalwithholding response, often termed "nutritional immunity," to restrict the availability of

*Corresponding Author.1nolan@mit.edu. ASSOCIATED CONTENT

Supporting Information.

The Supporting Information is available free of charge on the ACS Publications website. Complete experimental methods, Tables S1S3, Figures S1-S8. 
essential metal nutrients. ${ }^{1}$ Human calprotectin $(\mathrm{CP})$ is a metal-chelating protein that contributes to this innate immune response. It employs an unusual hexahistidine site for sequestering divalent first-row transition metals, including $\mathrm{Mn}(\mathrm{II}){ }^{2}$ The ability of $\mathrm{CP}$ to affect $\mathrm{Mn}(\mathrm{II})$ availability was first recognized during studies of murine tissue abscesses infected with the Gram-positive opportunistic human pathogen Staphylococcus aureus ${ }^{3}$ and later examined for the Gram-negative gastrointestinal pathogen Salmonella enterica serovar Typhimurium. ${ }^{4}$ In the current work, performed to provide molecular understanding of the tug-of-war between $\mathrm{CP}$ and microbes for $\mathrm{Mn}$ (II), we employ biochemical and electron paramagnetic resonance (EPR) spectroscopic methods to evaluate metal competition between human $\mathrm{CP}$ and bacterial metal transport machinery. We focus on extracellular solute-binding proteins (SBPs) employed by two Gram-positive human pathogens for acquiring $\mathrm{Mn}$ (II) from the host, $\mathrm{MntC}$ of $S$. aureus ${ }^{5}$ and PsaA of Streptococcus pneumoniae. ${ }^{6}$ The results show that $\mathrm{CP}$ outcompetes both of these $\mathrm{Mn}$ (II)-acquisition proteins for $\mathrm{Mn}(\mathrm{II})$ under conditions of high $\mathrm{Ca}(\mathrm{II})$, as found in the extracellular environment.

$S$. aureus employs the ATP-binding cassette transport system MntABC when battling with $\mathrm{CP}$ for $\mathrm{Mn}(\mathrm{II}) .{ }^{3,7} \mathrm{MntC}$ is the SBP that scavenges Mn(II) from the extracellular space. Following $\mathrm{Mn}$ (II) capture, MntC delivers the $\mathrm{Mn}$ (II) ion to MntAB, which transports the divalent cation across the cell membrane to the cytoplasm. Although less is known about the competition between $\mathrm{CP}$ and $S$. pneumoniae for nutrient metals, a recent antibacterial activity study showed that $\mathrm{CP}$ inhibits the growth of $S$. pneumoniae. ${ }^{8} S$. pneumoniae expresses the ATP-binding cassette transporter PsaABC for $\mathrm{Mn}$ (II) acquisition, which is important for virulence. ${ }^{9} \mathrm{PsaA}$ is the SBP that scavenges $\mathrm{Mn}$ (II) from the extracellular space and brings the ion to PsaBC for cytoplasmic delivery.

Most reported studies that consider the interplay between $\mathrm{CP}$ and bacterial metal transport systems are at the cellular level and typically begin with a comparison of the growth inhibitory activity of CP against wild-type bacteria and knock-out strains that lack a component of the metal transport machinery under investigation. ${ }^{3,4,7}$ Biochemical and biophysical methods provide complementary methods for investigating metal competition at the host/pathogen interface. In particular, these approaches can afford direct assessment of the metal-ion speciation during competition between microbial and host proteins for metal ions.

In an effort to achieve a molecular picture of $\mathrm{Mn}$ (II) competition at the host $/$ microbe interface, we overexpressed and purified staphylococcal MntC and streptococcal PsaA. Guided by reported studies of these proteins, ${ }^{10}$ we prepared MntC and PsaA that lack the Nterminal lipid anchors and obtained soluble proteins during overexpression. We overexpressed and purified each SBP without an affinity tag, which afforded the proteins in high yield and purity (Tables S1-S3, Figures S1,S2, Supporting Information). Because the SBPs accumulated bound metals during purification (Table S1), we removed contaminating metal ions after chromatographic purification of the proteins, and obtained MntC and PsaA with notably low metal content (Table S2). Moreover, Mn(II) competition titrations with the metal-ion sensor ZP1 indicated that both SBPs outcompete ZP1 $\left(K_{\mathrm{d}, \mathrm{Mn}(\mathrm{II})}=550 \mathrm{nM}\right)^{11}$ for 1 equiv of Mn(II) (Figure S3), which confirmed that each SBP was obtained predominantly in 
the apo form and, as expected from prior studies, ${ }^{10 \mathrm{~b}, \mathrm{~d}}$ binds 1 equiv of Mn(II) with high affinity.

We designed a pull-down assay for evaluating Mn(II) speciation between the SBPs and CP. We prepared biotinylated CP (B-CP), which has a biotin moiety covalently attached to Cys3 of S100A9 and established that it displays $\mathrm{Ca}$ (II)-dependent heterotetramerization, antibacterial activity comparable to the unmodified protein, and coordinates $\mathrm{Mn}$ (II), $\mathrm{Fe}$ (II) and $\mathrm{Zn}$ (II) with the expected stoichiometries (Figures S4,S5). Next, we prepared solutions containing $18 \mu \mathrm{M} \mathrm{Mn}(\mathrm{II}), 20 \mu \mathrm{M} \mathrm{SBP}$, and $20 \mu \mathrm{M}$ B-CP in the absence and presence of 400 $\mu \mathrm{M} \mathrm{Ca}$ (II) at $\mathrm{pH}$ 7.5. We selected a long, 10-h time point for this preliminary experiment because we lacked information about timescale required for the mixture to reach equilibrium. Following removal of B-CP with streptavidin resin (Figure S6), we analyzed the $\mathrm{Mn}$ (II) content of the solution by inductively-coupled plasma mass spectrometry (Figure 1). In the absence of $\mathrm{Ca}(\mathrm{II}),>80 \%$ of $\mathrm{Mn}$ (II) remained in solution, presumably bound by the SBP. In contrast, in the presence of $\mathrm{Ca}(\mathrm{II}),<4 \%$ of $\mathrm{Mn}$ (II) remained in solution, indicating that B-CP outcompeted the SBPs for Mn(II) and the pull-down removed Mn(II) from solution. These data provide evidence that the $\mathrm{Ca}$ (II)-bound, high-affinity form of $\mathrm{CP}$ coordinates $\mathrm{Mn}$ (II) with greater affinity than $\mathrm{MntC}$ or PsaA. This $\mathrm{Ca}(\mathrm{II})$-bound $\mathrm{CP}$ species is expected to exist in the extracellular space where $\mathrm{Ca}$ (II) concentrations are $\approx 2 \mathrm{mM} .^{12,13}$

Because removal of B-CP from solution by streptavidin resin takes minutes, we limited application of this pull-down assay to the end-point analysis. Moreover, we sought to directly observe and discriminate $\mathrm{Mn}$ (II) bound to CP and the SBPs in the same assay mixture at varying time points. Low-temperature EPR spectroscopy is ideally suited for this purpose because previous structural studies demonstrate that the Mn(II)-binding sites of $\mathrm{CP}$ and the SBPs have notably distinct coordination environments and degrees of symmetry. The high-affinity $\mathrm{Mn}(\mathrm{II})-\mathrm{His}_{6}$ site of CP shows a nearly idealized octahedral coordination geometry. ${ }^{2 \mathrm{a}-\mathrm{c}}$ In contrast, a crystal structure of $\mathrm{MntC}$ indicates that it coordinates $\mathrm{Mn}(\mathrm{II})$ at a 5-coordinate $\mathrm{N}_{2} \mathrm{O}_{3}$ motif composed of two His, one bidentate Glu, and one Asp residue. ${ }^{10 \mathrm{~b}}$ A crystal structure of Mn(II)-bound PsaA shows that it binds Mn(II) with the same residues as $\mathrm{MntC}$, but the site has been described as tetrahedral where the Glu and Asp residue are reported to be monodendate ligands. ${ }^{10 \mathrm{e}, 13}$ We reasoned that the different $\mathrm{Mn}$ (II) coordination environments in CP and the SBPs would result in readily distinguishable lowtemperature $\mathrm{Mn}(\mathrm{II})$ EPR spectroscopic signatures, ${ }^{14}$ providing spectral discrimination between $\mathrm{Mn}$ (II)-CP and Mn(II)-SBP in a sample. Prior EPR spectroscopy of the Mn(II)-His 6 site of CP revealed a six-line pattern centered at $g=2(\approx 335 \mathrm{mT})$ with a low zero-field splitting (ZFS) of $485 \mathrm{MHz}(E / D=0.30)$ for the $\mathrm{Mn}(\mathrm{II})$ ion $(\mathrm{S}=5 / 2)$, consistent with a highly symmetric site. ${ }^{2 \mathrm{a}, \mathrm{b}}$ On the basis of the crystallographic characterization of the Mn(II)-SBP sites, we expected that Mn(II) EPR spectra of these proteins would exhibit larger ZFS. ${ }^{14,15}$

To evaluate the EPR spectra of Mn(II) bound to the SBPs, we prepared samples containing 1 $\mathrm{mM}$ SBP and $750 \mu \mathrm{M}$ Mn(II) (75 mM HEPES, $100 \mathrm{mM} \mathrm{NaCl}$, pH 7.5). Both of the Mn(II)SBP spectra (Figure 2) indicate a high-spin Mn(II) ion $(S=5 / 2)$ with a large ZFS that is of comparable magnitude to the microwave quanta at X-band $(\approx 9.4 \mathrm{GHz}) .{ }^{14 a}, 15 \mathrm{~b}, 16$ The large ZFS ( $D>3 \mathrm{GHz}$ ) leads to these systems not being in the "high field" regime at X-band which 
is met when the electron Zeeman is the dominant term in the spin Hamiltonian and results in broad spectra that span $>600 \mathrm{mT}$ at X-band. ${ }^{15 \mathrm{c}}$ Multi-frequency EPR studies are needed to further evaluate the electronic structure of the $\mathrm{Mn}$ (II) ions coordinated by $\mathrm{MntC}$ and PsaA; however, the current spectra provide suitable handles for monitoring $\mathrm{Mn}$ (II) competition between these proteins and CP. In contrast to the Mn(II)-PsaA EPR spectra in Figure 2, a previously reported Mn(II)-PsaA spectrum showed 6-line Mn(II) EPR features at $g=2$ $(\approx 335 \mathrm{mT}),{ }^{17}$ which likely arose from aqueous Mn(II) contamination.

As anticipated, the EPR spectra of the Mn(II)-SBPs are markedly different than those of $\mathrm{Mn}$ (II)-CP or aqueous $\mathrm{Mn}(\mathrm{II})$, allowing simultaneous monitoring of $\mathrm{Mn}$ (II)-bound $\mathrm{CP}$ and MntC or PsaA (Figure S7). The sharp spectral features in the $g=4.5$ region $(\approx 150 \mathrm{mT})$ of the $\mathrm{Mn}$ (II)-SBP spectra do not overlap with the $\mathrm{Mn}$ (II)-CP signals in the $g=2$ region $(\approx 335$ $\mathrm{mT}$ ). Thus, to examine Mn(II) speciation between CP and the SBPs by EPR spectroscopy, we prepared samples containing a 1:1:1 ratio of $\mathrm{Mn}(\mathrm{II}), \mathrm{CP}$, and $\mathrm{SBP}(500 \mu \mathrm{M}$ each) in the absence and presence of $5 \mathrm{mM} \mathrm{Ca}(\mathrm{II})$ at $\mathrm{pH} 7.5$ and incubated them for $10 \mathrm{~h}$ at room temperature. In the samples without added $\mathrm{Ca}(\mathrm{II})$, we observed a distinct low-field feature around $g=4.5$ ( $\approx 150 \mathrm{mT}$, Figure 3A,C; black spectra) that corresponds to $\mathrm{Mn}$ (II)-MntC or $\mathrm{Mn}(\mathrm{II})-\mathrm{PsaA}$ and a weak Mn(II)-CP-Ser signal centered at $g=2(\approx 335 \mathrm{mT}$, Figure 3B,D; black spectra). In the presence of excess $\mathrm{Ca}(\mathrm{II})$, a strong Mn(II)-CP-Ser signal (Figure 3B,D; red spectra) and a negligible Mn(II)-SBP signal (Figure 3A,C; red spectra) occur, indicating that $\mathrm{Ca}(\mathrm{II})$-bound $\mathrm{CP}$ outcompetes both SBPs for $\mathrm{Mn}(\mathrm{II})$. These results are consistent with the pull-down assays performed in the absence and presence of $\mathrm{Ca}$ (II), where negligible $\mathrm{Mn}$ (II) was found in the SBP-containing supernatant after pull-down of B-CP only when excess $\mathrm{Ca}(\mathrm{II})$ was present (Figure 1). Moreover, this work provides further information about the Mn(II) affinity of CP. Prior studies indicate that the $\mathrm{His}_{6}$ site coordinates $\mathrm{Mn}$ (II) with $K_{\mathrm{d}} \leq 10 \mathrm{nM}$ when $\mathrm{Ca}(\mathrm{II})$ ions are present. ${ }^{11}$ The current results indicate that this value is in the sub-nanomolar range based on the reported $K_{\mathrm{d}, \mathrm{Mn}(\mathrm{II})}$ values of $\mathrm{MntC}\left(\mathrm{K}_{\mathrm{d}} \approx 4\right.$ $\mathrm{nM})^{10 \mathrm{~b}}$ and PsaA $\left(K_{\mathrm{d}}<10 \mathrm{nM}\right){ }^{10 \mathrm{~d}}$

Next, to probe the timescale of Mn(II) transfer from each SBP to CP, we performed EPR experiments where a solution containing $1 \mathrm{mM} \mathrm{CP}$ and $10 \mathrm{mM} \mathrm{Ca(II)} \mathrm{was} \mathrm{added} \mathrm{to} \mathrm{an} \mathrm{equal}$ volume of a solution containing $1 \mathrm{mM} \mathrm{Mn}$ (II)-SBP. Aliquots of this mixture were frozen at varying time points and analyzed by EPR spectroscopy (Figure 4). This assay revealed a time-dependent decrease in the $\mathrm{Mn}(\mathrm{II})-\mathrm{MntC}$ or $\mathrm{Mn}(\mathrm{II})-\mathrm{PsaA}$ signal (Figure 4A,C) and a corresponding increase in the Mn(II)-CP-Ser signal (Figure 4B,D). The greatest changes in signal intensity marking transfer of the $\mathrm{Mn}$ (II) ion from each SBP to CP occurred in the first $10 \mathrm{~min}$ of the time course. The short time-scale of $\mathrm{Mn}$ (II) transfer is striking and highlights the remarkable ability of $\mathrm{CP}$ to capture and retain labile divalent transition metals.

In closing, to our knowledge, this work provides the first direct analysis of metal speciation between CP and a metal-capturing SBP. Together, these experiments demonstrate that the $\mathrm{Ca}$ (II)-bound, high-affinity form of CP outcompetes MntC and PsaA, two SBPs used by Gram-positive pathogens for $\mathrm{Mn}$ (II) acquisition. This conclusion informs the current model of how CP contributes to extracellular metal withholding at the host/pathogen interface, and provides an important benchmark for future studies of this system and other microbial metal 
transporters. In particular, we expect that investigations of metal competition between $\mathrm{CP}$ and fully reconstituted $\mathrm{ABC}$ transporter systems will be informative.

\section{Supplementary Material}

Refer to Web version on PubMed Central for supplementary material.

\section{Acknowledgments}

This work was supported by the NIH (R01GM118695 to EMN and R01GM104543 to RDB). R. C. Hadley is a recipient of the R. R. Schrock Graduate Fellowship, and T. G. Nakashige is a recipient of a NSF graduate fellowship. The MIT Biophysical Instrumentation Facility for the Study of Complex Macromolecular Systems is supported by NSF grant 0070319. The ICP-MS instrument is housed in the MIT CEHS Bioanalytical Core, which is supported by NIH grant P30-ES002109. We thank Prof. D. P. Giedroc for his comments on the manuscript, and Prof. Giedroc and Dr. John Lisher for contributing a $S$. pneumoniae D39 genomic DNA fragment containing the psaA sequence, and J. R. Stephan and E. M. Zygiel for assistance with protein purifications. S. aureus USA300 JE2 was obtained from the Network on Antimicrobial Resistance Against Staphylococcus aureus.

\section{References}

1. (a) Weinberg ED. J. Am. Med. Assoc. 1975; 231:39-41.(b) Hood MI, Skaar EP. Nat. Rev. Microbiol. 2012; 10:525-537. [PubMed: 22796883]

2. (a) Hayden JA, Brophy MB, Cunden LS, Nolan EM. J. Am. Chem. Soc. 2013; 135:775-787. [PubMed: 23276281] (b) Gagnon DM, Brophy MB, Bowman SEJ, Stich TA, Drennan CL, Britt RD, Nolan EM. J. Am. Chem. Soc. 2015; 137:3004-3016. [PubMed: 25597447] (c) Damo SM, Kehl-Fie TE, Sugitani N, Holt ME, Rathi S, Murphy WJ, Zhang Y, Betz C, Hench L, Fritz G, Skaar EP, Chazin WJ. Proc. Natl. Acad. Sci. U. S. A. 2013; 110:3841-3846. [PubMed: 23431180] (d) Nakashige TG, Zhang B, Krebs C, Nolan EM. Nat. Chem. Biol. 2015; 11:765-771. [PubMed: 26302479] (e) Nakashige TG, Stephan JR, Cunden LS, Brophy MB, Wommack AJ, Keegan BC, Shearer JM, Nolan EM. J. Am. Chem. Soc. 2016; 138:12243-12251. [PubMed: 27541598] (f) Nakashige TG, Zygiel EM, Drennan CL, Nolan EM. J. Am. Chem. Soc. 2017; 139:8828-8836. [PubMed: 28573847]

3. Corbin BD, Seeley EH, Raab A, Feldmann J, Miller MR, Torres VJ, Anderson KL, Dattilo BM, Dunman PM, Gerads R, Caprioli RM, Nacken W, Chazin WJ, Skaar EP. Science. 2008; 319:962965. [PubMed: 18276893]

4. Diaz-Ochoa VE, Lam D, Lee CS, Klaus S, Behnsen J, Liu JZ, Chim N, Nuccio S-P, Rathi SG, Mastroianni JR, Edwards RA, Jacobo CM, Cerasi M, Battistoni A, Ouellette AJ, Goulding CW, Chazin WJ, Skaar EP, Raffatellu M. Cell Host Microbe. 2016; 19:814-825. [PubMed: 27281571]

5. Gribenko, AV., Liberator, P., Anderson, AS., Matsuka, YV., Mosyak, L. Encylopedia of Inorganic and Bioinorganic Chemistry. John Wiley \& Sons, Ltd; 2015.

6. Eijkelkamp BA, McDevitt CA, Kitten T. Biometals. 2015; 28:491-508. [PubMed: 25652937]

7. Kehl-Fie TE, Zhang Y, Moore JL, Farrand AJ, Hood MI, Rathi S, Chazin WJ, Caprioli RM, Skaar EP. Infect. Immun. 2013; 81:3395-3405. [PubMed: 23817615]

8. Makthal N, Nguyen K, Do H, Gavagan M, Chandrangsu P, Helmann JD, Olsen RJ, Kumaraswami M. EBioMedicine. 2017; 21:131-141. [PubMed: 28596134]

9. (a) Ogunniyi AD, Mahdi LK, Jennings MP, McEwan AG, McDevitt CA, Van der Hoek MB, Bagley CJ, Hoffmann P, Gould KA, Paton JC. J. Bacteriol. 2010; 192:4489-4497. [PubMed: 20601473] (b) Rajam G, Anderton JM, Carlone GM, Sampson JS, Ades EW. Crit. Rev. Microbiol. 2008; 34:131142. [PubMed: 18728990] (c) Eijkelkamp BA, Morey JR, Ween MP, Ong C-IY, McEwan AG, Paton JC, McDevitt CA. PLoS One. 2014; 9:e89427. [PubMed: 24558498]

10. (a) Anderson AS, Scully IL, Timofeyeva Y, Murphy E, McNeil LK, Mininni T, Nuñez L, Carriere M, Singer C, Dilts DA, Jansen KU. J. Infect. Dis. 2012; 205:1688-16896. [PubMed: 22474033] (b) Gribenko A, Mosyak L, Ghosh S, Parris K, Svenson K, Moran J, Chu L, Li S, Liu T, Woods VL Jr, Jansen KU, Green BA, Anderson AS, Matsuka YV. J. Mol. Biol. 2013; 425:3429-3445. [PubMed: 23827136] (c) Salazar N, Castiblanco-Valencia MM, da Silva LB, Arantes de Castro Í, 
Monaris D, Masuda HP, Barbosa AS, Arêas APM. PLoS One. 2014; 9:e112730. 22. [PubMed: 25409527] (d) McDevitt CA, Ogunniyi AD, Valkov E, Lawrence MC, Kobe B, McEwan AG, Paton JC. PLoS Pathog. 2011; 7:e1002357. [PubMed: 22072971] (e) Couñago RM, Ween MP, Begg SL, Bajaj M, Zuegg J, O'Mara ML, Cooper MA, McEwan AG, Paton JC, Kobe B, McDevitt CA. Nat. Chem. Biol. 2014; 10:35-41. [PubMed: 24212134]

11. You Y, Tomat E, Hwang K, Atanasijevic T, Nam W, Jasanoff AP, Lippard SJ. Chem. Commun. 2010; 46:4139-4141.

12. Brini M, Ottolini D, Cali T, Carafoli E. Met. Ions Life Sci. 2013; 20:87-93.

13. Brophy MB, Nolan EM. ACS Chem. Biol. 2015; 10:641-651. [PubMed: 25594606]

14. Stich TA, Lahiri S, Yeagle G, Dicus M, Brynda M, Gunn A, Aznar C, DeRose VJ, Britt RD. Appl. Magn. Reson. 2007; 31:321-341. [PubMed: 22190766]

15. (a) Walsby CJ, Telser J, Rigsby RE, Armstrong RN, Hoffman BM. J. Am. Chem. Soc. 2005; 127:8310-8319. [PubMed: 15941264] (b) Whittaker JW, Whittaker MM. J. Am. Chem. Soc. 1991; 113:5528-5540.(c) Vance CK, Miller AF. Biochemistry. 2001; 40:13079-13087. [PubMed: 11669646]

16. (a) Un S, Tabares LC, Cortez N, Hiraoka BY, Yamakura F. J. Am. Chem. Soc. 2004; 126:27202726. [PubMed: 14995187] (b) Tabares LC, Cortez N, Agalidis I, Un S. J. Am. Chem. Soc. 2005; 127:6039-6047. [PubMed: 15839704]

17. Li N, Yang XY, Guo Z, Zhang J, Cao K, Han J, Zhang G, Liu L, Sun X, He QY. J. Biol. Inorg. Chem. 2014; 19:829-838. [PubMed: 24553956] 

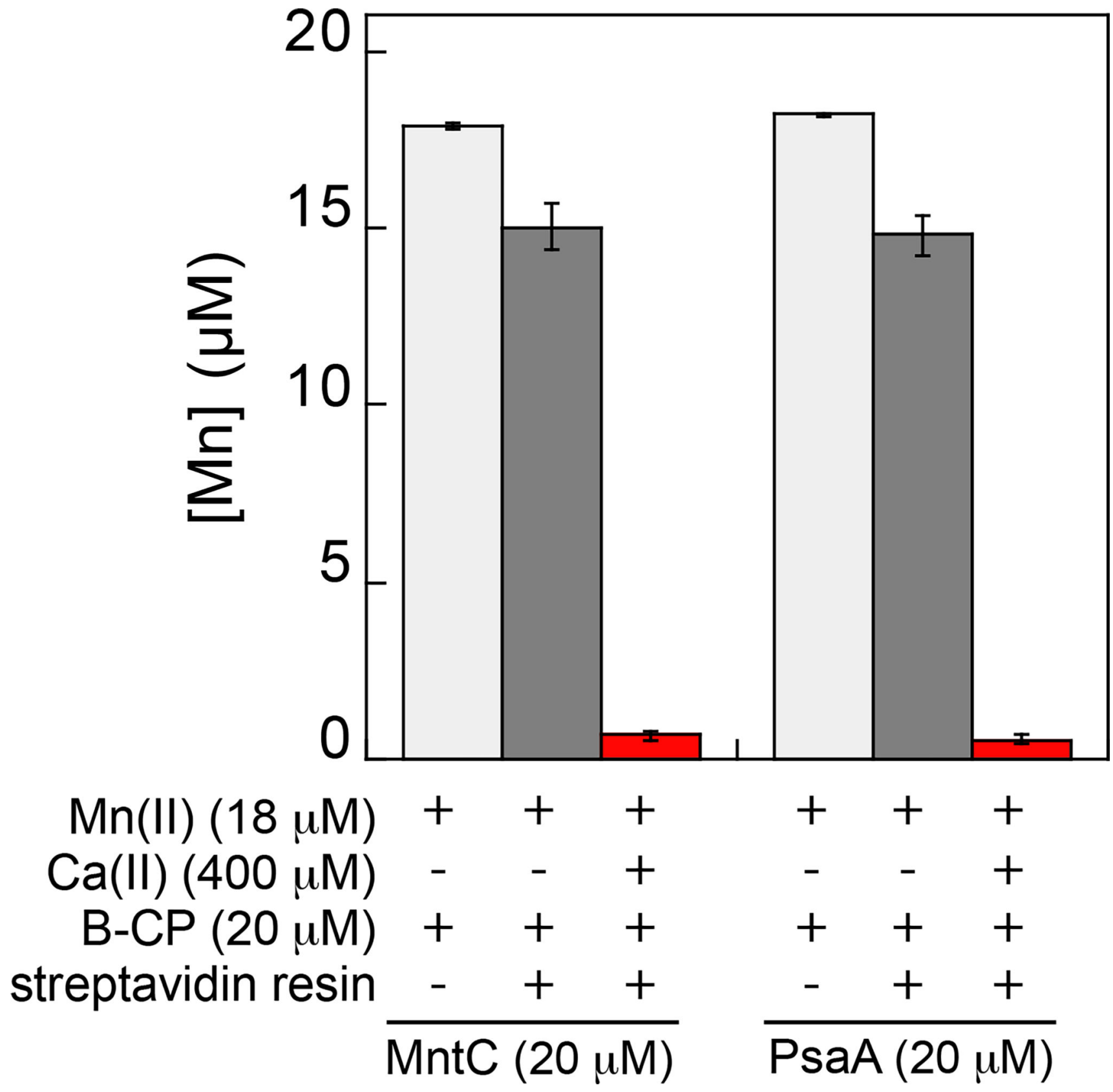

Figure 1.

Concentration of $\mathrm{Mn}(\mathrm{II})$ in solution following pull-down of mixtures containing B-CP, MntC or PsaA, and Mn(II) with or without Ca(II) (75 mM HEPES, $100 \mathrm{mM} \mathrm{NaCl}, \mathrm{pH}$ 7.5). The mixtures were incubated for $10 \mathrm{~h}$ at room temperature before pull-down. 


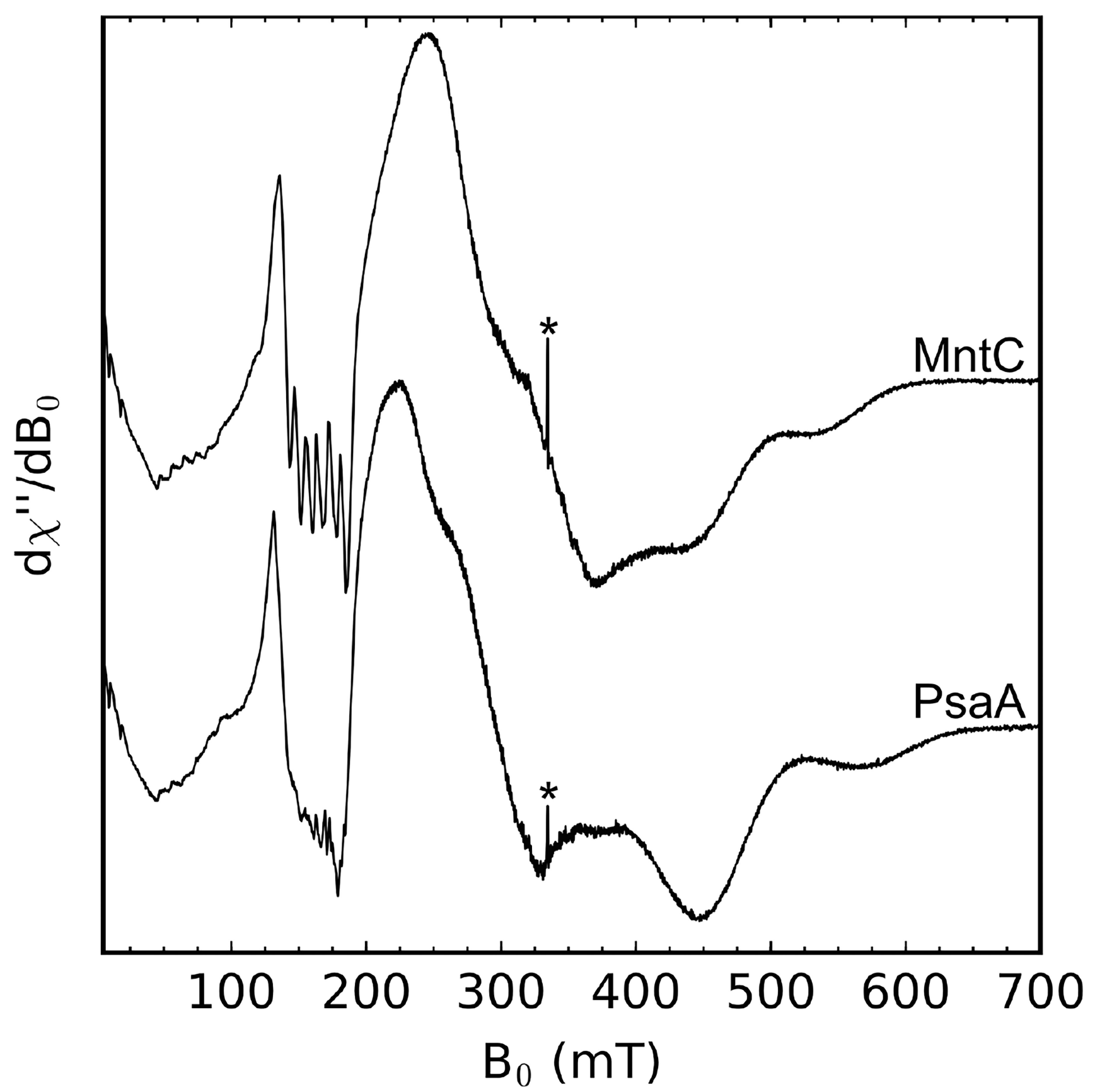

Figure 2.

X-band CW EPR spectra of Mn(II) $(750 \mu \mathrm{M})$ bound to MntC (1 mM) or PsaA (1 mM) (75 mM HEPES, $100 \mathrm{mM} \mathrm{NaCl}, \mathrm{pH}$ 7.5). The asterisk denotes a quartz background radical. Spectrometer settings: $v_{\mathrm{mw}}=9.4 \mathrm{GHz}, 0.5 \mathrm{mT}$ modulation amplitude at $100 \mathrm{kHz}$, power $=$ $200 \mu \mathrm{W}, \mathrm{T}=10 \mathrm{~K}$. 

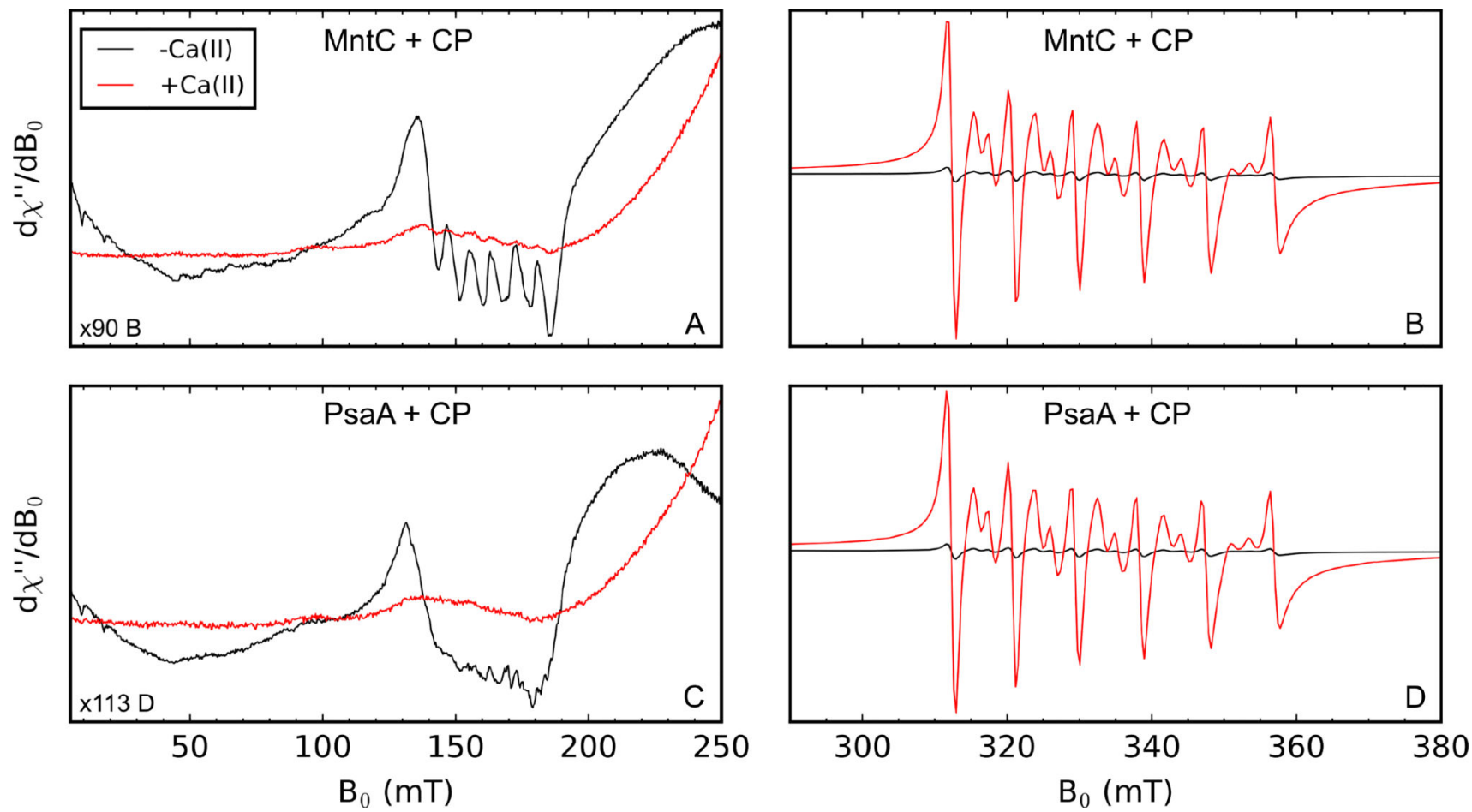

Figure 3.

X-band CW EPR of 1:1:1 mixtures of Mn(II):CP:SBP incubated for $10 \mathrm{~h}$ at room temperature in the absence (black) or presence (red) of $5 \mathrm{mM} \mathrm{Ca(II)} \mathrm{(75} \mathrm{mM} \mathrm{HEPES,} 100$ $\mathrm{mM} \mathrm{NaCl}, \mathrm{pH} 7.5)$. Each sample contained $500 \mu \mathrm{M} \mathrm{Mn}(\mathrm{II}), 500 \mu \mathrm{M} \mathrm{SBP}$, and $500 \mu \mathrm{M} \mathrm{CP}$ after mixing. Panels $\mathrm{A}$ and $\mathrm{C}$ contain the same $\mathrm{Mn}(\mathrm{II})$ spectra of the samples containing $\mathrm{CP}$ and MntC, and panels B and D contain the same Mn(II) spectra of the samples containing $\mathrm{CP}$ and PsaA. Panels A and $\mathrm{C}$ are scaled differently from $\mathrm{B}$ and $\mathrm{D}$ along the $\mathrm{y}$-axis to make the low-field, $g=4.5$, features of each Mn(II)-SBP more apparent relative to the mid-field features, $g=2$, of $\mathrm{Mn}(\mathrm{II})-\mathrm{CP}$. Spectrometer settings: $v_{\mathrm{mw}}=9.4 \mathrm{GHz}, 0.5 \mathrm{mT}$ modulation amplitude at $100 \mathrm{kHz}$, power $=200 \mu \mathrm{W}, \mathrm{T}=10 \mathrm{~K}$. 

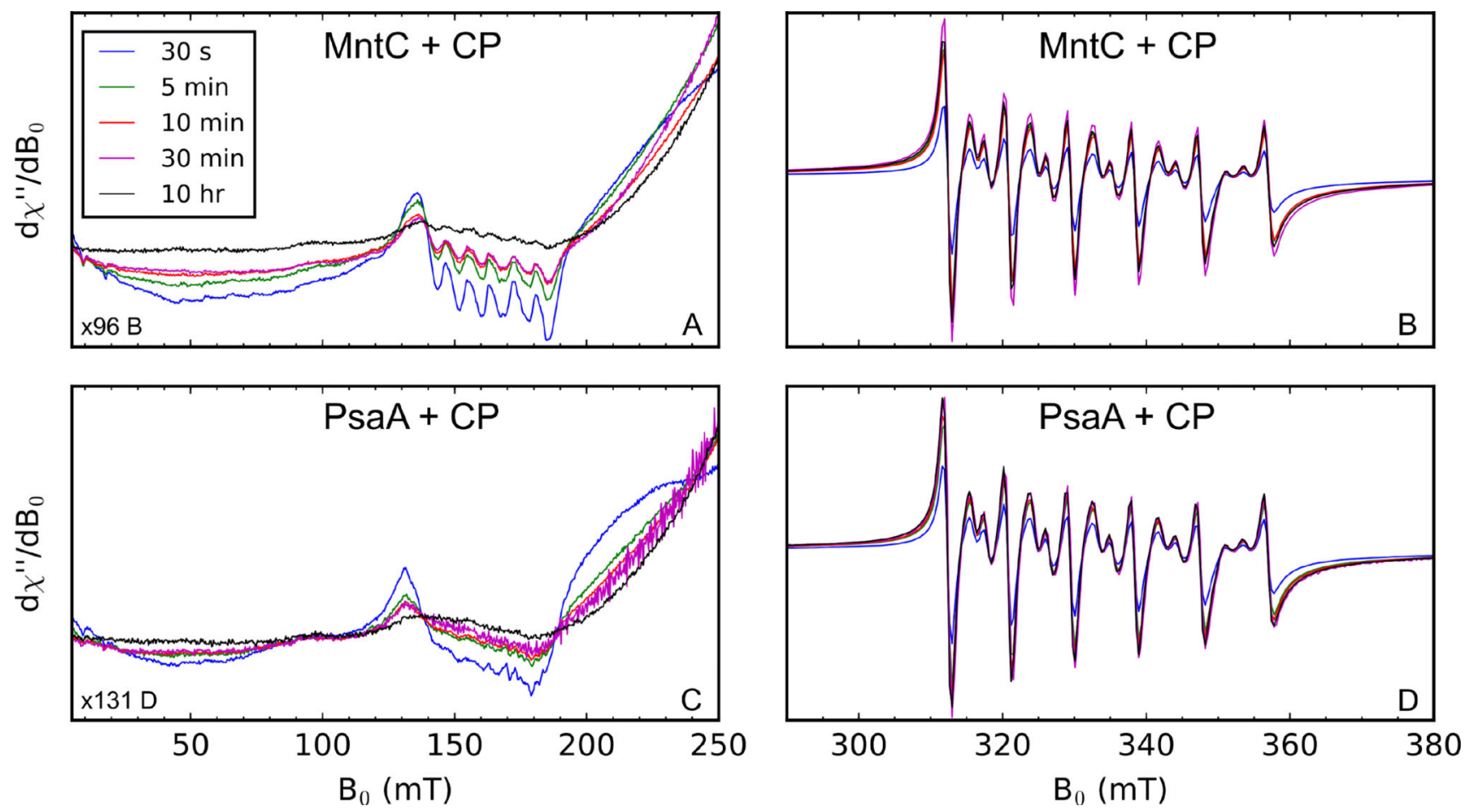

Figure 4.

Time course of $\mathrm{Mn}(\mathrm{II})$ transfer from $\mathrm{Mn}$ (II)-SBPs $(500 \mu \mathrm{M})$ to $\mathrm{CP}(500 \mu \mathrm{M})$ in the presence of $5 \mathrm{mM} \mathrm{Ca}$ (II) monitored by X-band EPR spectroscopy (75 mM HEPES, $100 \mathrm{mM} \mathrm{NaCl}$, $\mathrm{pH}$ 7.5). Panels $A$ and $C$ contain the same $\mathrm{Mn}(\mathrm{II})$ spectra of the samples containing $\mathrm{CP}$ and MntC, and panels B and D contain the same Mn(II) spectra of the samples containing CP and PsaA. Panels A and C are scaled differently from B and D along the y-axis to make the low-field, $g=4.5$, features of each Mn(II)-SBP more apparent. Spectrometer settings: $v_{\mathrm{mw}}=$ $9.4 \mathrm{GHz}, 0.5 \mathrm{mT}$ modulation amplitude at $100 \mathrm{kHz}$, power $=200 \mu \mathrm{W}, \mathrm{T}=10 \mathrm{~K}$. 